\title{
The International Union of Geodesy and Geophysics.
}

THE third conference of the Intprational Union of Geodesy and Geophts on held at Prague on Sept. 3-10, at the invitg iff of the Czechoslovakian Government, thouf ofst of the seations found it neccssary to hold $A_{\text {me }}$ of their moltirgs in the preceding week in order to get, the of work. Previous meetifintheld at Rome in 1922, and at Madrid in 1924, fad proved to be of great value in providing an opprortunity for workers in a group of sciences where international co-operation is essential to discuss methods and to arrange sehernes for future work.

On the present occasion, 29 out of the 32 countries belonging to the Union were represented by delegates, who numbered more than 160. The Union, with its sections for geodesy, seismology, meteorology, terrestrial magnotism and electricity, oceanography, volcanology, and hydrology, covers a very wido field, and these triennial meetings afford an oceasion when questions involving two or more of these fields of work can be discussed by those who are actually occupied with them.

In the Section of Geodesy the determinations of gravity at sea, made by Dr. Vening Meinesz of Holland on board a submarine during a voyage to Port Said, and also during one to Java by way of the Panama Canal, were described by him, and aroused much interest. The great ocean areas were shown to be generally in a state of approximate isostatic equilibrium, oxcopt in places where crustal movement is in progress, such as the Straits of Sunda, whero consider'able anomalies were shown to exist. 'The conference expressed the hope that other nations having submarines of a suitable typo will co-operate in this work of gravity determination over oecan areas now that a satisfactory method of doing so has been developed, and proved to be efficient. Dr. Vening Meinesz also doseribod eertain improvements in his pendulum apparatus which he had introduced as the result of his experiences on submarine cruises. Detailed accounts of this work will be published by the Dutch Geodetic Commission.

The goodetic work which has been carried out recently on a co-operative plan by the countrios on the shores of the Baltic furnished an example of an excellent piece of work, well designed and carefully carried out. It was suggested that such work might bo done usefully in other restricted areas by similar co-operation. Summaries of geodetic work carried out since the last conference were communicated by many countries, and were thus made available to other geodesists much sooner than would othorwise have been the case.

In seismology much useful work was done in the discussion of the analysis of soismograms, the improvoment of telegraphic codes, the proparation of tablos for use in the reduction of seismological data, etc. The conference urged that the countries concerned should improve the network of existing stations by establishing additional ones in North Spain, in the Balearic Islands, and in Now Calodonia or Tahiti. A proposal of the National Committee for the Uniled States that countries should co-operate in the study of ocoan deeps was strongly supported.

The Soction of Meteorology was occupied with a large number of scientific questions, among which the preparation of daily synoptic charts of the South Pacific Ocean, the extended study of solar radiation, and upper air observations in tropical regions and in the southorn hemisphere, may be mentioned. The conference adopted a recornmendation of the Soction expressing the hope that this investigation of the upper air in low and southern latitudes might be actively prosecuted. Now that the International Meteorological Committee finds itself vory fully occupied with matters relating to the working of the meteorological services of the various countries, this Section of the Geodetic and Geophysical Union finds full employment in the discussion of many scientific matters which would probably not be dealt with by the Committee; thus, each of the two organisations work without duplicating the work of the other, but on the contrary supplementing it.

The Section of Terrestrial Magnetism had a full programme of work which included the discussion of recent work, the comparison of instruments, the design of improved apparatus, and the reduction of observations. Atmospheric ionisation and the observation of aurora also came under consideration, as well as the need for additional earth-current installations.

The Section of Oceanography did much of its work by sub-committees appointed to consider the investigation of the different grent sea areas, and of tidal phenomena.

In volcanology full accounts were communicated of the recent outburst of Vesuvius, and also of the somewhat earlier volcanic activity at the island of Santorin. Certain problems connected with the transmission of waves in the earth's crust were discussed in a joint meeting with the Section of Seismo$\log y$, and the thermal gradient in the crust came up for detailed consideration. The conference adopted a resolution by the Section that countries in which active volcanoes occur should be invited to undertake the moasuromont of the thermal gradient in various localities.

In hydrology much work was dono on problems relating to the flow of water, and the transport of silt in suspension also came under discusion. By an arrangement with the International Committee on Glaciers, which was established in 1894, its work will now be transferred to and carried on by a committee of the Section of Hydrology, of which committee $M$. Hamberg will be the chairman and M. Mercanton the secretary.

M. Lallemand was re-elected president of the Union up to the end of 1931, when the statutes may be revised and re-approved by the countries of the Union. $\mathrm{He}$ will thus have been president throughout the whole of the first period of the Union's activity, twelve years. Some changes were made in the officers of the sections, Dr. L. A. Bauer replacing Dr. C. Chree as presidont of the Section of 'Terrestrial Magnetism, and being in turn replaced as secretary by $\mathbf{M}$. Ch. Manrain. $M$. Wehrlé becomes secretary of the Section of Meteorology.

The various communications which were made to the sections at their meetings will be published by them in the immediate future, in continuntion of the publication serios which each section has already initiated.

The most generous hospitality was shown to tho delegates both by the Czechoslovakian Government and by the municipality of the city of Prague. In addition, the mombors of tho organising committee made excollent arrangements, by which the delegates wore shown all the scientific institutions of importance as well as the numerous museums, galleries, and houses of historical and artistic interest in and near the city.

The Prosident of the Republic was to have recoived the delegates on one evening, but unfortunately his health did not allow him to return to Prague to do

No. 3022, VoL. 120] 
so ; the Minister of Foreign Affairs held the reception on his behalf.

On the conclusion of the conference delegates had the choice of visiting the Tatra Mountains in southeastern Czechoslovakia, or the principal health resorts, including Joachimstal, Keilberg, Karlsbad, and Marienbad.

For the next meeting the conference received in- vitations to meet at Stockholm and at Lisbon; both were accepted in principle, but it was left to the executive committee to decide later which of the two should be definitely accepted, since the wish had been expressed by the United States Research Council that the Union's meeting should take place near in time and place to that of the International Astronomical Union, whenever this should be practicable.

\section{International Congress of Genetics.}

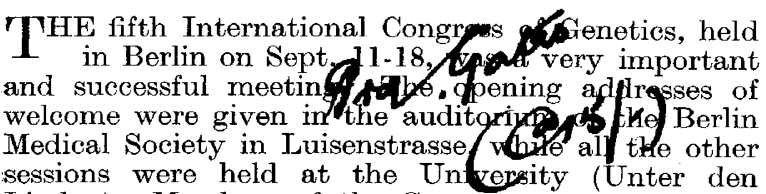
Linden). Members of the Congress were welcomed by Prof. E. Baur, chairman of the committee of arrangements, as well as by the German Minister of the Interior, the Prussian Minister of Agriculture, the head of the Berlin Medical Service, and Prof. Kniep, representing the University of Berlin. At this meeting an address was given by Prof. $R$. von Wettstein on the problem of evolution. Prof. S. Navashin, the distinguished cytologist of Moscow, was elected president of the Congress, a fact which is significant of the fundamental part which cytology has played in the modern development of genetics. The membership of the Congress numbered more than 1000. Mornings were devoted to general addresses, while in the afternoon the Congress met in six sections and about 135 papers were read.

The sections devoted to general genetics, cytology, and cultivated plants were particularly strong. The largest number of papers were devoted to wheat, maize, Drosophila and Enothera, as many as ten investigators of Enothera being present. A number of papers were concerned with the subject of mutation; several were concerned with the statistics of inheritance, and several with crossing-over. A double attack on the theory of crossing-over led to an extensive and lively discussion in which the great strength of the theory was brought out. In this connexion an important paper by Prof. F. Bernstein pointed out new mathematical relationships which follow from the mechanical theory of crossing-over.

The address of Prof. H. J. Muller, of Texas, on the production of mutations in Drosophila by treatment with X-rays, was generally regarded as the most important contribution to the Congress. Mutations were produced in large numbers by subjecting males or females to $\mathrm{X}$-rays for different periods. Four periods were used, and with the longest period of treatment the rate of mutation was 150 times that in the controls. Genes were affected equally throughout the chromatin and an increase in the $\mathrm{X}$-ray dosage was found to increase the rate of "point" mutations. Sperm used in fertilisation 6 days or 12 days after treatment showed no difference in the rate of mutation-production. The presence of large numbers of mutations was also found to have little or no effect on sperm viability.

In the X-chromosome of Drosophila, mutations normally appear at the rate of not more than 1 in 1000. In these experiments many more mutations appeared in the $\mathrm{X}$-chromosome than have occurred in it naturally in all previous experiments. Such well-known mutations as rudimentary wing, broad wing, cross-veinless, white eye, and vermilion eye appeared repeatedly, but there was an enormous increase in the number of lethal factors. It was also found that the effect of X-rays on the ovaries per- sisted after treatment, a fact which has an important bearing on some of the present methods of X-ray therapy. X-rays also increased the number of c-factors, which reduce the frequency of crossing-over. Rearrangements of loci were also found to occur in the chromosomes. From various experiments the conclusion is reached that the gene is probably compound in the chromosome, composed of 2 or 4 parts, in preparation for later cell divisions. The great majority of the mutations produced are lethal or otherwise invisible, their presence being proved by later breeding experiments.

In the genetic work on Anothera, the greatest interest centred around the linkages between chromosomes, which were demonstrated by Cleland and Gates. Each species and mutation is found to have a fixed arrangement of its chromosomes during diakinesis and on the heterotypic spindle. In some wild species all the chromosomes are linked into a ring of 14, while in others there are 7 free pairs. Still other species, such as $C_{E}$. lamarckiana and $\sigma_{E}$. ammophila, have 1 free pair and a ring of 12 . In the mutations from $E$. lamarckiana the arrangement is also a definite one, $E$. rubrinervis and $E$. rubricalyx, for example, having 4 free pairs with a ring of 6 chromosomes, while $Q E$. deserens has 7 free pairs.

This constitutes essentially a new type of nuclear differentiation. It appears that it will also be of fundamental importance as furnishing the basis for the unique phenomena of linkage of characters into complexes in Cnothera, which has not hitherto received an explanation. It is already indicated that where a large amount of chromosome linkage occurs there will be only two (twin) or three hybrid types, while in crosses betweon forms with many free pairs of chromosomes much segregation will occur. Shull described a new gene mutation from $(E$. lamarckiana, a simple Mendelian recessive showing linkage of the ordinary type.

Among the studies of cereals, Dr. C. L. Huskins showed the existence of speltoid and dwarf wheats having respectively $41,42,43$, and 44 chromosomes, parallel to the fatuoid series which he has recently discovered in oats. He also described a fatuoid chimara in outs, and this appears to complete the parallelism in the behaviour of fatuoid oats and speltoid wheat.

Dr. M. Navashin made an important demonstration of the nuclear differences in species and hybrids of Crepis. Some of the species differ in the presence of a satellite or a terminal ' head' to the chromosome, and in the hybrids it is shown that the former may be transformed into the latter. This is the first time that a definite change in the structure of a chromosome as the result of hybridisation has been shown. The study of this type of chromosome differentiation is in its infancy and will lead to large results.

Among general addresses to the Congress may be mentioned that of Prof. O. Rosenberg, of Stockholm, on species-formation with multiplication of chromosomes, and Prof. H. Federley, of Helsingfors, on the

No. 3022, VoL. 120$]$ 